\title{
Correspondence
}

Letters for publication in the Correspondence columns should be addressed to:

The Editor, British Journal of Psychintry, 17 Belgrave Square, London SWIX 8PG

\section{IMIPRAMINE AND DEPRESSION}

Dear Str,

Davis \& Erikson in their letter (Journal, August 1976 , 129, p 192) not only suggest that we should criticize the findings of Rogers and Clay (Joumal, December 1975, 127, p 599) but claim that imipramine is not effective as an antidepressant. We did not wish this emphasis to be placed on our letter, which was intended to convey the view that the place of antidepressants in the treatment of depressive illness needs more clarification. Our concern was that Rogers and Clay's paper might lead to a premature closure of the discussion on the suitability of antidepressants for individual patients. Individual psychiatrists may vary a great deal in their views, as can be seen in recent correspondence in the British Medical foumal (Brewer 1976, Revill 1976, Sargant 1976).

We have already noted that some of the data (in our view) in Rogers and Clay's tabulation might not be as 'hard' and acceptable as would be desired. At a basic statistical level, studies with a sample size of less than 20 may be of questionable validity. If these are omitted, the following summary data emerge which have a different implication from that of Rogers and Clay's original table:

\begin{tabular}{|c|c|c|}
\hline & Imipramine & Placebo \\
\hline $\begin{array}{l}\text { Endogenous } \\
\text { Depression } \\
\text { (Acute) }\end{array}$ & $\begin{array}{l}\text { I I improve out } \\
\text { of } 161=69 \%\end{array}$ & $\begin{array}{l}50 \text { improve (145) } \\
=35 \%\end{array}$ \\
\hline $\begin{array}{l}\text { Mixed } \\
\text { Depression }\end{array}$ & $\begin{array}{l}72 \text { improve } \\
(101)=71 \%\end{array}$ & $\begin{array}{l}46 \text { improve ( } 71) \\
=65 \%\end{array}$ \\
\hline $\begin{array}{l}\text { Neurotic } \\
\text { Depression }\end{array}$ & $\begin{array}{l}60 \text { improve (82) } \\
=73 \%\end{array}$ & $\begin{array}{l}9 \text { improve (100) } \\
=9 \%\end{array}$ \\
\hline
\end{tabular}

First, the percentage of patients improving on imipramine is very similar whatever the type of depression, although the variation with placebo is very large. This revised table might suggest that prescribers expect two thirds of depressions (of any sort) to improve on an active drug. Differences, not always obvious, between an active drug and a bland placebo may well lead to bias in the interpretation of clinical response.

Without denigrating Rogers and Clay's paper, we wish to suggest the picture is far from clear. Their conclusion "the benefit of this drug in patients with endogenous depression who have not become institutionalized is indisputable' goes too far. Antidepressants may be effective, but we still need to know how well they work, and with whom, before final conclusions are drawn.

\section{R. J. KeRRY \\ Consultant Psychiatrist \\ J. E. Orase \\ Chief Psychologist}

Middlewood Hospital

Sheffield S6 ITP

\section{REFERENCEs}

Brewer, C. (1976). Suicide with tricyclic antidepressants. British Medical Journal, ii, 110.

Duvis, J. M. \& Errkson, S. E. (1976). Controlled trials of imipramine. British fournal of Psychiatry, 128, 192.

Kerry, R. J. \& OrMr, J. E. (1976). Controlled trials of imipramine. British Journal of Psychiatry, 128, 310.

Revill, M. G. (1976). Suicide with tricyclic antidepressants. British Medical Journal, ii, 475 .

Roozrs, S. C. \& ClAY, P. M. (1975). A statistical review of controlled trials of imipramine and placebo in the treatment of depressive illnesses. British Joumal of Psychiatry, 127, 599-603.

Sargant, W. (1976). New look at monoamine oxidase inhibitors. British Medical Journal, ii, 423.

\section{THE TEACHING OF PSYCHIATRY}

\section{Dear Sir,}

As a senior student at St George's Hospital, I have just finished a three month appointment in psychiatry. This has given me the 'once only' opportunity to take a fresh view of the subject. As a result, I think I have recognized a simple but nevertheless profound imbalance in the approach of modern psychiatry.

My point is that far too much attention is paid to unravelling the problems that an individual has developed, and far too little effort is put into encouraging and developing the germs of positive direction.

We assume that this latter part is easy, and that patients will do this as soon as their problems are 
out of the way. I think it is more difficult; I think it is the deepest demand on the therapist. It will usually involve teasing out tentative, and practically unformed priorities, and giving them the right culture-medium of interest and enthusiasm to grow. They won't just be sitting there, fully formed, waiting to get out; they need to be fertilized.

If constant self-analysis is indulged in, these little hopes, often tenuous enough as it is, will become smothered. But without them, there can be no will to emerge from the difficulties, whatever pattern these may have assumed. The reason for this misguided emphasis is not difficult to understand: we have, as in all branches of science, become obsessed with mechanism. There are a million ways in which an imbalance can evolve; they are almost infinitely complex, and therefore fascinating-too fascinating. It is our detached interest as scientists and intellectuals that has beguiled us into caring more about explaining than helping.

All of us could spend the rest of our lives understanding the ins and outs of our imperfections, but, when it comes down to it, the only problems worth giving one's attention to are those which specifically obstruct our growth.

Roland Peters

12 Southrwood Lane

Highgate Village, N6

\section{HISTORIES OF PSYCHIATRIC HOSPITALS}

DeAR SIR,

Many psychiatric hospitals for mental illness and mental handicap were established in the later years of last century or in the early twentieth century and they are now passing their jubilees or reaching their centenaries. These occasions present an opportunity to review their histories. At present it is often not easy to obtain the interest of the lay press or the public in the publishing of histories of psychiatric hospitals. Nevertheless it is important that histories and facts should be recorded while there are still staff closely identified with these hospitals and who possess the background of knowledge about a hospital's development and achievements.

In the future the study of the histories of psychiatric hospitals may become a more popular topic of study, and historians will then have cause to be grateful for the information which has been accumulated. Psychiatric hospitals have relieved the community over the years of an enormous burden of hard work, distress and misery, and their contribution to the common weal, which it is at present fashionable to devalue, may ultimately be recognized for its true worth.

Meanwood Park Hospital
Leeds LS6 $4 Q B$

D. A. Spencer

\section{READING LIST IN PSYGHATRY}

The Third Edition of the Reading List is available on request to the Royal College of Psychiatrists, 17 Belgrave Square, London SW IX 8PG. Price 30p per copy. Please enclose payment with your order (plus the cost of postage) together with a self-addressed envelope. The list measures $270 \mathrm{~mm} \times 215 \mathrm{~mm}$ and weighs $50 \mathrm{gm}$. 